\title{
Bird Flu, the Hanging Pandemic Threat for Human - It's Risk Assessment and Containment
}

\author{
MAnwar Hossain*, M Intakhar Ahmad and M Manjurul Karim \\ Department of Microbiology, University of Dhaka, Dhaka 1000, Bangladesh
}

[Received 06 June 2008; Accepted 14 June 2008]

\begin{abstract}
Bird flu, synonym of avian influenza (AI) caused by influenza A virus, become concern across the world for the possible incidence of the next human influenza pandemic. The latent danger of AI pandemic remains very real, though, the precise timing of occurrence and severity is uncertain. Each avian influenza type $A$ (AIA) contains one of the 16 subtypes of haemagglutinin (HA) and 9 neuraminidases (NA) implicating theoretically 144 subtypes of AIA are possible in circulation, but only H1N1, H2N2 and H3N2 subtypes are documented for past pandemics in humans. In recent years H5N1, H7N3, H7N2, H7N7 and H9N2 are isolated from human samples, though $\mathrm{H} 1 \mathrm{~N} 1$ and $\mathrm{H} 3 \mathrm{~N} 2$ are still in circulation. Avian influenza viruses preferentially recognize receptor containing sialosugar chains terminating in sialic acid $\mathbf{- 2 , 3 - g a l a c t o s e}$ in bird, whereas, human preferentially contain -2,6-galactose subtype-receptor. To initiate a pandemic outbreak in human, the AIA viruses need alteration of receptor recognition specificity; and perfect match between HA and NA along with optimal cellular tropism. Cyclic nature of bird-flu emergence, and moreover, sporadic human incident reported around Asia and Europe in recent years anticipating a pandemic appearance of bird-flu in time to come. As we are on the edge of this alarming situation, AI prevention and containment can be considered under categories of surveillance, intervention, antiviral drugs, vaccination together with environment management issues.
\end{abstract}

Keywords: Pandemic, Avian influenza, Genetic reassortment, Host specificity, Environment management

\section{Introduction}

"Avian influenza" or "fowl plague" was first recognized in chickens in $1878^{1}$. Influenza, an RNA virus can be designated as $\mathrm{A}, \mathrm{B}$ or $\mathrm{C}^{2}$ based on their antigenic differences. Influenza A viruses being the most dangerous one mutate and spread rapidly, and can infect different birds to mammalians including human and subtype on the basis of surface protein named as haemagglutinin (HA) and neuraminidase (NA) ${ }^{2-7}$. There are 16 known HA and 9 known NA subtypes ${ }^{7}$. Many different combinations of HA and NA proteins are possible p $^{3-7}$. Theoretically, 144 subtypes are likely. So far about 100 subtypes have been notified ${ }^{2}$. Generally, influenza viruses are highly species-specific ${ }^{3,6}$. All known subtypes of influenza A viruses can be found in birds ${ }^{3}$. Intestinal cells of wild birds, especially shorebirds, ducks, and geese display receptors for AI viruses and regarded as the natural reservoir of all AI viruses ${ }^{8-9}$. Genetic mutation and re-assortment help viruses capable to jump over the species barrier making them capable to infect human ${ }^{7,10}$ (Figure 1 and Table 1).

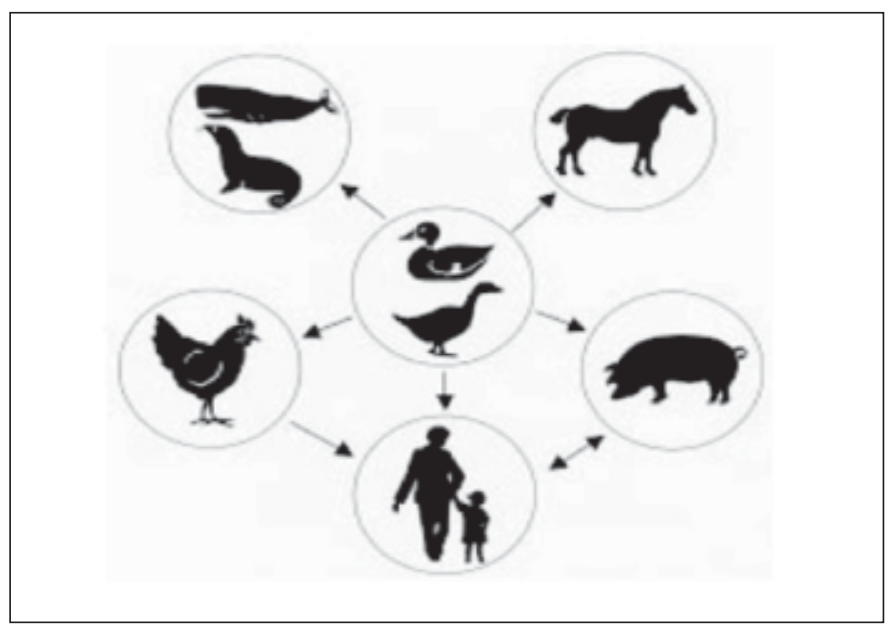

Figure 1. Transmission of avian influenza viruses among hosts. Wild aquatic birds are the primary reservoir for influenza $A$ viruses from which viruses can be transmitted to other hosts such as horses, pigs, poultry, whales, seals, and humans. Pigs and poultry can also infect humans. (Adapted from Trampuz et al. $\left.{ }^{11}\right)$. 
Table 1. Instances of various subtypes of avian influenza A virus infections of human ${ }^{12-13}$

\begin{tabular}{|c|c|c|}
\hline Subtype & Region & Year \\
\hline $\mathrm{H} \mathrm{N7}^{\mathrm{a}}$ & USA & 1959 \\
\hline H7N7 & UK & 1995 \\
\hline H7N7 & UK & 1996 \\
\hline $\mathrm{H} 5 \mathrm{~N} 1^{\mathrm{a}}$ & Hong Kong & 1997 \\
\hline H9N2 & China and Hong Kong & 1999 \\
\hline H7N2 & USA(Virginia) & 2002 \\
\hline $\mathrm{H} 5 \mathrm{~N} 1^{\mathrm{a}}$ & China and Hong Kong & 2003 \\
\hline H7N7a & Netherlands & 2003 \\
\hline H9N2 & Hong Kong & 2003 \\
\hline H7N2 & USA (New York) & 2003 \\
\hline $\mathrm{H} \mathrm{N}^{\mathrm{a}}$ & Canada & 2004 \\
\hline $\mathrm{H} 5 \mathrm{~N} 1^{\mathrm{a}}$ & Thailand and Vietnam & 2004 \\
\hline $\mathrm{H} 5 \mathrm{~N} 1^{\mathrm{a}}$ & Thailand, Vietnam, Cambodia, China and Indonesia & 2005 \\
\hline $\mathrm{H} 5 \mathrm{~N} 1^{\mathrm{a}}$ & $\begin{array}{l}\text { Thailand, Vietnam, Cambodia, China, } \\
\text { Indonesia, Azerbaijan, Djibouti, Egypt, } \\
\text { Iraq and Turkey }\end{array}$ & 2006 \\
\hline $\mathrm{H} 5 \mathrm{~N} 1^{\mathrm{a}}$ & $\begin{array}{l}\text { Bangladesh, Vietnam, Cambodia, China, } \\
\text { Indonesia, Laos, Nigeria and Egypt }\end{array}$ & 2007 \\
\hline H7N2 & UK & 2007 \\
\hline H9N2 & China and Bangladesh & 2007 \\
\hline $\mathrm{H} 5 \mathrm{~N} 1^{\mathrm{b}}$ & Bangladesh & 2008 \\
\hline
\end{tabular}

${ }^{\mathrm{a}}$ High pathogenic; ${ }^{\mathrm{b}} \mathrm{Pathogenicity} \mathrm{is} \mathrm{not} \mathrm{clear,} \mathrm{because} \mathrm{the} \mathrm{infected}$ 16-month-old boy did not show any avian influenza (AI) symptom.

The epidemic nature and the clinical features of this deadly influenza first recorded at the beginning of $19^{\text {th }}$ century. Several epidemics recorded during the nineteenth century but the first pandemic outbreak of Bird flu not recorded precisely ${ }^{11-14}$. In 19181919, a pandemic known as 'Spanish flu' recorded about 50 million deaths, principally the young adults ${ }^{15}$ suggesting unusual virulence nature of the strain. On the other hand, the large numbers of deaths may be due to the enfeebling conditions as an after effect of the First World War ${ }^{15-17}$. Pandemics continued to occur regularly after the Spanish influenza, in 1932-1933, 1947-1948, 1957 and 1968. The next pandemic is thought to be overdue. These latter pandemics resembled the pandemic of 1890 , affecting millions of people with a mild upper respiratory tract infection (URTI) and a small number of deaths. The H1N1 (swine) viruses probably appeared in 1918 and continued in circulation until supplanted by the H2N2 (Asian) viruses in 195718-26. The H2N2 viruses predominantly circulated until H3N2 (Hong Kong) strains appeared in 1968. The H1N1 virus reappeared in 1977 and did not replace the H3N2 subtype and both subtypes continued to co-circulate ${ }^{6,19}$ (Figure 2).

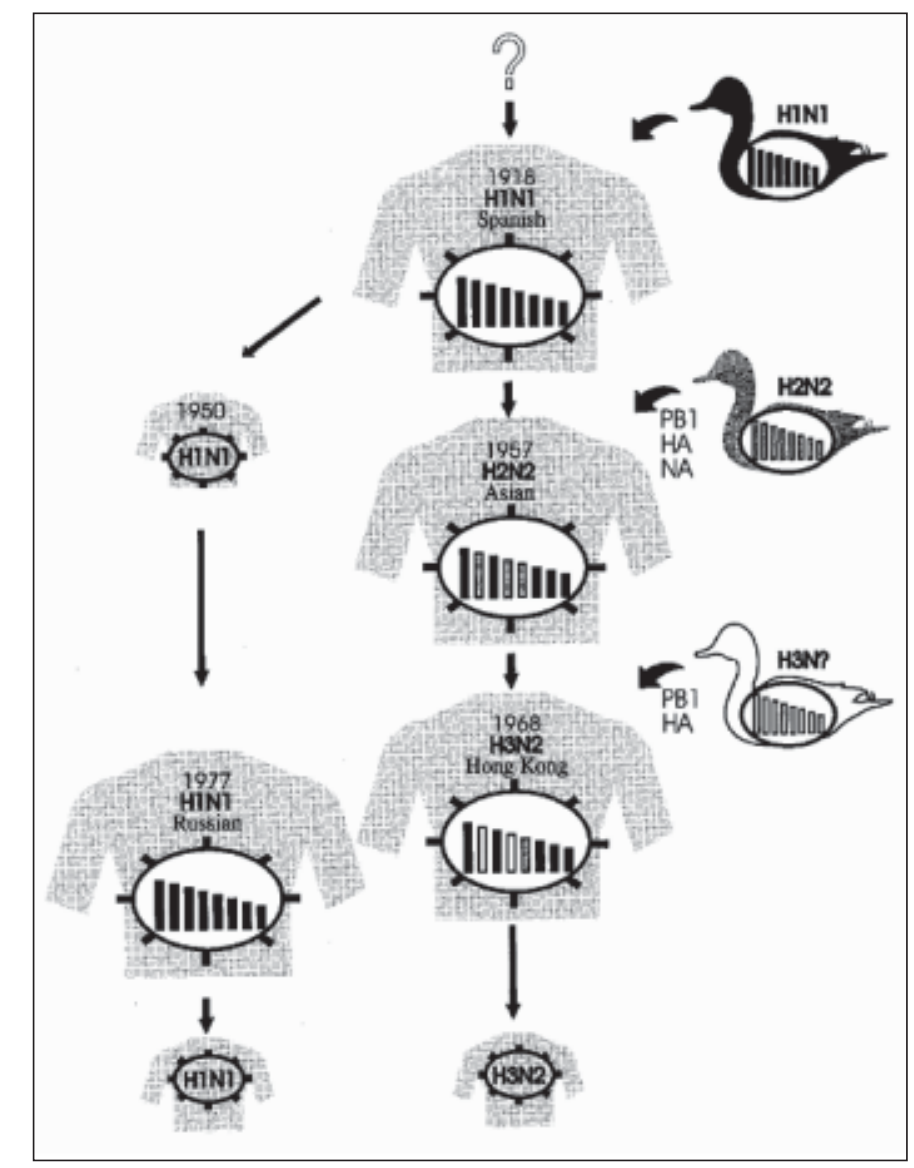

Figure 2. Possible origins of pandemic influenza viruses. Phylogenetic studies suggest that an avian influenza virus was transmitted to humans, caused the 1918 pandemic. A reassortment virus possessing its $P B 1, H A$, and NA genes from $a$ Eurasian avian virus, with the remainder coming from an H1N1 human virus, caused the Asian pandemic of 1957. In 1968, a reassortment possessing its $P B 1$ and HA genes from a Eurasian avian virus and the remainder from an H2N2 human virus emerged, followed by the disappearance of the H2N2 virus. In 1977, a virus genetically almost identical to those circulating in humans in 1950 appeared and spread among children and young adults. The H1N1 and H3N2 viruses are now co-circulating in humans (Adapted from Taisuke et al. ${ }^{27}$ ).

Depending on the severity all subtypes can be categorized into two kinds. One is high pathogenic avian influenza virus (HPAIV) and the other is low pathogenic avian influenza virus (LPAIV). When LPAIV strains are transmitted from avian reservoir hosts to highly susceptible poultry species such as chickens and turkeys, they undergo a series of mutations resulting adaptation to their new hosts ${ }^{27-28}$. Influenza A virus not only runs through a host adaptation phase in this way, HPAIVs may arise unpredictably de novo in poultry infected with LPAI progenitors ${ }^{24}$. Over the last 30 years, highly virulent avian influenza viruses have caused outbreaks in poultry in Australia $\left(1976[\mathrm{H} 7]^{30}, 1985[\mathrm{H} 7]^{31-32}\right.$, $1992\left[\right.$ [H7 $^{33}$, 1995 [H7] and 1997 [H7]), England (1979 [H7] ${ }^{34}$ and $1991[\mathrm{H} 5]^{35}$ ), the United States (1983 to $1984[\mathrm{H5}]^{36}$ ), Ireland (1983 
to $1984[\mathrm{H} 5]^{37}$ ), Germany (1979 [H7] ${ }^{38}$ ), Mexico (1994 to 1995 [H5] $\left.{ }^{39-40}\right)$, Pakistan (1995 [H7] $\left.{ }^{41}\right)$, Italy (1997 [H5]) and Hong Kong (1997 [H5] ${ }^{42}$ ). Recently, H5 and H9 have been demonstrated to be involved with poultry flu in Bangladesh. Among the two, H5N1 (93\%) is predominant according to the National Reference Laboratory, Bangladesh Livestock Research Institute (BLRI), Savar, Dhaka. The available information implicating with minor exception that all of the recent pathogenic avian influenza A viruses are of $\mathrm{H} 5$ or $\mathrm{H} 7$ containing subtypes (Table 1).

\section{Molecular Perspective of Pandemic Risk}

For a pandemic an agent should have three properties ${ }^{43}$.

1. A new type of flu virus has to be introduced into the human population.

2. The new type must have a serious impact on the health of humans.

3. The new type must have the capability to spread easily from one person to the next (human specific variant).

Currently circulating $\mathrm{H} 5$ and $\mathrm{H} 7$ subtypes attained the first two properties and the third one is yet to acquire ${ }^{30}$. Host specification primarily depends on HA, the surface glycoprotein ${ }^{33-34}$. In addition, there is increasing evidence that NA can promote virus entry into host cells during the initial stage of infection ${ }^{44}$. The pandemic risk lies within the molecular composition of these two structural proteins. Influenza infection requires binding of the HA protein to sialic acid-containing receptors on the host cell surface where the precise linkage of HA to host receptors determines species preference ${ }^{38}$. For example, a switch in receptor specificity from receptors containing sialic acids connected to galactose in a alpha 2-3 linkage (avian receptors) to a alpha 2-6 linkage (human receptors) is required for influenza A virus to cross the species barrier to adapt in human host ${ }^{45-48}$. Antigenic properties also change with $\mathrm{it}^{49}$. Pandemic strains of H1, H2, and H3 subtypes recognize alpha 2-6 linked sialic acid, the prevalent form found on cells of the human respiratory tract ${ }^{50}$. But researchers found that human airway epithelium harbours alpha 2-3 linked sialic acids on ciliated cells. These findings suggest that although avian influenza viruses can infect human ciliated airway epithelium, their replication may be limited by a non-optimal cellular tropism ${ }^{51}$. Bangladesh health authorities confirmed on the $22^{\text {nd }}$ May 2008 that a 16-month-old boy infected with H5N1 without showing any symptom of bird flu, had recovered and released from hospital. Thus, the present data and experimental evidence implicating that to be a HPAIV strain - the strain must have $\alpha-2,6$ receptor specificity and capable to evade cellular control that limit it's replication or pathogenesis.

Genetic alteration is likely high for avian influenza A virus ${ }^{52}$. For the lack of proofreading activity of RNA polymerases, there is much more inherent variation at the nucleotide sequence level in a replicating population of an RNA virus than for an otherwise similar DNA viruses ${ }^{53-54}$. The effects of natural selection can produce evolutionary change in viruses over a shorter time scale. For influenza, according to natural selection, superior evader variants of body's immune response have better replicative success in human populations ${ }^{55}$.

Influenza virus genome is spliced into 8 pieces $^{7}$. And various strains of influenza A virus can productively infect multiple mammalian and avian species. This co-hosting phenomenon is a good reason for genetic reassortment to evolve viruses with new-fangled characteristics. Mixed infections occur frequently in nature and thus lead to genetic reassortment ${ }^{56-58}$. Furthermore, major antibodyinteracting domains of HA lack specific conserved structure and distinct from the main functional domains ${ }^{59}$. Per year a given strain of influenza virus may change by a percent at the nucleotide sequence level ${ }^{53}$. HA contains about 566 amino acid residues $(1.75 \mathrm{~kb})^{60}$. Over a decade, a given "strain” of influenza virus can change quite significantly resulting flu from the same strain, even if, the host is vaccinated. One important phenomenon for the potency of pandemic is the crosstalk and match between two surface proteins residing on the viral particle. High pathogenic HA is accompanied better with low-functional NA ${ }^{61}$.

\section{Classification of Pandemic Phases and Recent Pandemic Layout}

According to WHO experts' investigation, AI virus did not spread within the community. No healthcare worker was infected either. It showed that infection is only possible with very close contact with H5N1 infected patients ${ }^{64}$. Therefore, the world remains at phase 3 of the WHO alert scale (Table 2). One key point to focus, besides H5N1 (the recently isolated pathogenic form of AIA from the human patient of different countries) other potential pandemic viruses H7N7, H9N2, and H2N2 are also the threat and candidate for pandemic, because they are still in circulation and showed high virulence potential in laboratory samples ${ }^{12-13,65}$.

Table 2. WHO classification of pandemic phases ${ }^{62-63}$

\begin{tabular}{lll}
\hline Warning status & Phase & Human risk situation \\
\hline Inter-pandemic & Phase 1 & Low risk of human cases \\
& Phase 2 & High risk of human cases \\
& Phase 3 & $\begin{array}{l}\text { No or very limited human-to-human } \\
\text { transmission }\end{array}$ \\
Pandemic alert & Phase 4 & $\begin{array}{l}\text { Evidence of increased human-to-human } \\
\text { transmission }\end{array}$ \\
& Phase 5 & $\begin{array}{l}\text { Evidence of significant human-to-human } \\
\text { transmission }\end{array}$ \\
Pandemic & Phase 6 & $\begin{array}{l}\text { Efficient and sustained human-to-human } \\
\text { transmission }\end{array}$ \\
\hline
\end{tabular}

\section{Major Strategies to Fight Bird Flu Pandemic}

WHO had included surveillance for pandemic preparedness, public health interventions, the use and availability of antiviral, and access to vaccines produce against the infectious AIA as four major topics for discussion in "WHO consultation on priority public health interventions before and during an influenza pandemic” held in March $2004^{66}$. 


\section{Strategy I - Surveillance and early detection}

The important function of surveillance is to detect unusual cluster of cases at an early stage or to discover abnormal clinical manifestations in cases and then to understand virus characteristics through analysis. This will help us block the virus in time, once its transmission ability enhances and will facilitate the execution of epidemic control measures to prevent the epidemic situation from worsening.

\section{Strategy II - Interruption of transmission}

Besides medical interventions of bird flu using antiviral agents and vaccines, non-medical public health interventions such as personal hygiene practices, isolation, an reduction of social contact have been demonstrated extremely effective in preventing and minimizing the spread of the pathogen. WHO Global Influenza Preparedness Plan ${ }^{67}$ categorized non-pharmaceutical public health interventions into 4 types:

1. Measures that limit the international transmission of virus, such as screening of fever at border and travel restriction,

2. Measures that reduce virus transmission, such as isolated treatment of patient, health self-management of contact, quarantine, cancellation of rallies and class suspension, etc.,

3. Decrease personal risks, such as frequent practice of handwashing and

4. Communication of risks to the public.

A recent research found that border restrictions and/or internal travel restrictions are unlikely to delay spread by more than 2-3 weeks, school closure during the peak of a pandemic can reduce peak attack rates by up to $40 \%$, and treatment of clinical cases can reduce transmission, but only if antiviral is given within a day of symptoms starting ${ }^{68}$. Given enough drugs for $50 \%$ of the population, household-based prophylaxis coupled with reactive school closure could reduce clinical attack rates by $40-50 \%{ }^{68-69}$. More widespread prophylaxis would be even more logistically challenging and might reduce attack rates by over $75 \%{ }^{70}$.

\section{Strategy III - Antiviral drugs}

At present, the cure and preventive function of neuraminidase inhibitor anti-viral drugs have been confirmed in seasonal influenza ${ }^{71}$. As a consequence, it is expected to be effective in treatment and after exposure prophylaxis for avian influenza and pandemic influenza.

There are 2 classes of anti-viral drugs specific for influenza: M2 inhibitors and neuraminidase inhibitors. M2 inhibitors launched earlier and are cheaper. A major concern is that $\mathrm{H} 5 \mathrm{~N} 1$ virus has been found to be resistant to M2 inhibitors ${ }^{72}$. Neuraminidase inhibitors, such as Oseltamivir and Zanamivir, are newly developed. Neuraminidase inhibitors are effective in the treatment of avian influenza especially when given early, in the first 48 hours of infection ${ }^{73}$ but evidence shows higher incidence of resistance (AI H5N1 strains resistant to Oseltamivir have been collected in $0.4-4.0 \%$ of patients $)^{74}$. Factors, which might contribute to this apparently limited efficacy, include suboptimal dosing or routes of administration, suboptimal timing of treatment, the inability of antiviral drugs to interfere with immunopathology and the development of drug resistance ${ }^{75}$. The promising news is that last year, Neugene, a new antiviral drug still in the testing phase, is showing promise as an effective treatment for avian flu. The new drug is manufactured by BioPharma, $\mathrm{Inc}^{76}$.

\section{Strategy IV - Vaccination}

Present vaccines have had mixed results. In the field of influenza vaccination, neither commercially available nor experimentally tested vaccines have been shown promising enough to fight this diseases perfectly ${ }^{77}$. A variety of vaccine types are employed, including inactivated (whole virion, split virus and surface antigen), live attenuated and virosome. The majority of projects target specific strains of influenza virus (H2N2, wild type H5N1, H5N1, H5N3, H7N1, H7N7, H9N2) ${ }^{78}$ (Table 3).

Table 3. Current development in avian influenza vaccine (2006 to 2007)

\begin{tabular}{ll}
\hline Vaccine type and formulation & Dose and year \\
\hline${ }^{\mathrm{a}}$ Split H5N1, no adjuvant & $2 \times 90 \mu \mathrm{g}(2006)^{77}$ \\
Split H5N1, with alum & $2 \times 30-45 \mu \mathrm{g}(2006)^{78}$ \\
${ }^{\mathrm{b}}$ Whole virus H5N1 (egg grown), with alum & $2 \times 10-15 \mu \mathrm{g}(2006)^{79-80}$ \\
& $1 \times 6 \mu \mathrm{g}(2007)^{81}$ \\
Subunit H5N3, with MF59 & $2 \times 7.5 \mu \mathrm{g}^{*}(2001)^{82}$ \\
${ }^{\mathrm{b}}$ Subunit H5N1, with MF59 & $2 \times 7.5 \mu \mathrm{g}(2007)^{83}$ \\
Vero cell whole virus H5N1 (wild type), & $2 \times 7.5 \mu \mathrm{g}^{*}(2007)^{84}$ \\
no adjuvant & $2 \times 1.9 *-3.75 \mu \mathrm{g}(2007)^{85}$ \\
\hline
\end{tabular}

a Licensed in the USA; bicensed in the Europe; *Not evaluated. Note: Food and Drug Administration of China issued license for a vaccine against H5N1, April, 2008.

Researchers believe that universal influenza vaccine is possible, using an M-2 peptide conjugate protein ${ }^{86}$. Recently A Novel Intranasal Virus-Like Particle (VLP) Vaccine have prepared bearing the surface glycoproteins HA and NA of the 1918 influenza A virus by infecting Sf9 cells with a quadruple recombinant baculovirus that expresses the four influenza proteins (HA, NA, $\mathrm{M} 1$ and M2) ${ }^{87}$. Vaccines are primarily geared towards ducks and chickens to save economic lose, though, it may cause host immunopressure resulting generation of antigenic diversity or more pathogenic variants ${ }^{88}$. Experimental result shows that when HA protein comes under selective immunopressure, it mutates to evade the host's immune system ${ }^{89}$.

Vaccination vary broadly in regard to several local factors (e.g., type of production, local pattern of disease, costs and potential losses) but vaccination should also be applied in the framework of poultry disease eradication program at national or regional 
levels under the official supervision of public veterinary services ${ }^{90}$. Recent data of N1 sequences in the NCBI database shows that $\mathrm{N} 1$ from H5N1 is distantly related to the H1N1 from 1918 and its descendants. N2 of different strains also feature the same type of relatedness ${ }^{13}$. So, new vaccine targeting both the $\mathrm{N} 1$ and N2 (combination vaccine) is however speculative to provide with partial protection because of cross-immunity. This might be enough to prevent death with a rapid pace.

\section{Factory Farming and Environmental Degradation Boosting Pandemic Threat}

Wild birds are the main reservoir of avian influenza virus ${ }^{11}$. They have been blamed for the spread of present influenza threat. In Canada, Quebec outlawed the outdoor raising of poultry $\left(12^{\text {th }}\right.$ November 2005) ${ }^{91}$. If wild birds had been spreading the disease across continents there would have been trails of dead birds following migration routes, which is not the case. Certain countries on flight paths of birds from Asia remain flu-free, whilst their neighbours suffer repeated infections ${ }^{92}$. Another interesting thing, in a low-density and dispersed population such as, flocks of wild birds a virus can only survive as a low pathogenic agent because if a virus mutates into a highly pathogenic form in these circumstances, it quickly dies out as it kills all available hosts ${ }^{93}$.

The necessity for efficiency to produce the animal protein the agribusiness has been especially moved to poultry sector, where it is now a reality, as many as 10 million birds are raised within a few square kilometers ${ }^{94-95}$. In a factory farm situation, perfect conditions exist for a virus to mutate from a low pathogenic to a high pathogenic form. Thousands of hosts (chickens) with near identical genetic makeup, all the same age and size, crowded in close conditions allow a virus to kill its host and move onto the next victim with great speed and ease ${ }^{96}$. The poultry industry should change and humanity must move toward raising poultry in smaller scale, under less stressful, less crowded and more hygienic conditions with outdoor access. Some useful practice can be introduced rearing animals (e.g., straw bedding is linked to decrease risk of infection with the influenza virus ${ }^{97}$ ).

Nutrition, sanitation and medication have improved in the last century but we have disrupted planetary ecological processes. Human activities like deforestation destroy birds natural habitat thus they are getting contract with our domesticated animals and giving the virus to widen its host range. Some of our strange farming strategies like fish-chicken integrated farm (where economic benefit is questionable ${ }^{98}$ ) prompts pandemic risk. Direct contamination of chicken excreta in fish rearing water bodies ${ }^{99}$ introduces a huge dose of pathogenic agent to a new environment (an infected chicken can contain enough virus to infect 1 million of individuals ${ }^{100}$ ). Pathogens that enter the food chain of farm animal have good potency to flourish largely because of stressrelated factors (overcrowding, competition, same age etc. ${ }^{101}$ ). This sort of desperate farming trend should be stopped under proper law and legislations.

\section{Conclusion}

Rapid spread rate in a dense population occurs in breeding ground of infectious diseases. The more the infectious agent circulates in human host, the more they get adapted with that. Most of the people in developing countries suffer from malnutrition. Respiratory diseases have good link with malnutrition. The condition is worse in sub-Saharan countries particularly in militaries. These people are veritably vulnerable to avian influenza. On the other hand, poultry is the fastest growing segment of global agriculture. Being in this dilemma, the Governments of over populated developing countries mainly in Asia and Africa should put in place an effective strategy for the prevention and control of bird flu in collaboration of FAO, WHO and other International Agencies to prevent the looming catastrophic potential of bird flu with great agency and implementation surety.

\section{References}

1. Perroncito CE. 1878. Epizoozia tifoide nei gallinacei [Typhoid epizootic in gallinaceous birds]. Torino: Annali Accademia Agricoltura. 21: 87-126.

2. NCBI. Avian influenza virus resource (Information search and analysis). Available at: http://www.ncbi.nlm.nih.gov/genomes/FLU/ flubiology.html. Accessed 03 November 2007.

3. CDC. 2007. Key facts about avian influenza (bird flu) and avian influenza A (H5N1) virus. Available at: http://www.cdc.gov/flu/avian/ gen-info/facts.htm. Accessed 06 November 2007.

4. Canadian Food Inspection Agency. 2007. Avian influenza - Frequently asked questions. Available at: http://www.inspection.gc.ca/english/ anima/heasan/disemala/avflu/queste.shtml. Accessed 02 November 2007.

5. Anonymous. 2007. US government site on pandemic flu. General information on pandemic influenza. Available at: http://www. pandemicflu.gov/general. Accessed 06 November 2007.

6. Anonymous. 2007. Influenza viruses. Available at: http://virologyonline.com/viruses/Influenza.htm. Accessed 06 November 2007.

7. NCBI. 2007. Taxonomy browser for influenza A viruses. Available at: http://www.ncbi.nlm.nih.gov/Taxonomy/Browser/wwwtax.cgi ?id= 197911. Accessed 06 November 2007.

8. Alexander DJ. 2000. A review of avian influenza. Vet Microbiol. 74: 3-13.

9. Oxford JS. 2000. Influenza A pandemics of the $20^{\text {th }}$ century with special reference to 1918 virology, pathology and epidemiology. Rev Med Virol. 10: 119-113.

10. Stefan R. 2006. Crossing the species barrier: The threat of an avian influenza pandemic. Proc Bayl Univ Med Cent. 19(1): 16-20.

11. Trampuz AJ, Prabhu RM, Smith TF \& Baddour LM. 2004. Avian influenza: A new pandemic threat. Mayo Clin Proc. 79: 523-530.

12. CDC. 2007. Avian influenza A virus infections of humans. Available at: http://www.cdc.gov/flu/avian/gen-info/avian-flu-humans.htm. Accessed 06 November 2007.

13. NCBI. 2007. Flu database. Available at: http://www.ncbi.nlm.nih.gov/ genomes/FLU/Database/select.cgi?go=1. Accessed 06 November 2007.

14. Anonymous. 2007. The pandemic of 1918-19 claimed at least 30 million human lives. Roche Pharmaceuticals, Switzerland. Available at: http://www.roche.com/pages/facets/16/spanflu.htm. Accessed 04 November 2007. 
15. Crosby AW. 2003. America's Forgotten Pandemic: The Influenza of 1918, $2^{\text {nd }}$ edn, pp 11-83. Cambridge University Press, Cambridge.

16. Reid AH, Fanning TG, Hultin JV \& Taubenberger JK. 1999. Origin and evolution of the 1918 "Spanish" influenza virus hemagglutinin gene. PNAS. 96(4): 1651-165.

17. Taubenberger JK \& Morens DM. 1918 influenza: The mother of all pandemics. Available at: http://www.cdc.gov/ncidod/EID/vol12no01/ 05-0979.htm. Accessed 01 November 2007.

18. Gernhart G. 1999. Forgotten Enemy: PHS's fight against the 1918 influenza pandemic. Public Health Rep. 114: 559-561.

19. Potter CW. 2001. A history of influenza. J Appl Microbiol. 91(4): 572-579.

20. Reid AH, Taubenberger JK \& Fanning TG. 2004. Evidence of an absence: The genetic origins of the 1918 pandemic influenza virus. Nat Rev Microbiol. 2(11): 909-914.

21. Reid AH \& Taubenberger JK. 2003. The origin of the 1918 pandemic influenza virus: A continuing enigma. J Gen Viol. 84(9): 2285-2292.

22. White J. 2007. Infectious diseases (influenza). Available at: http:// www.medicalecology.org/diseases/influenza/print_influenza.htm. Accessed 06 November 2007.

23. Tara CS. 2005. History of pandemic influenza. Available at http:// scienceblogs.com/aetiology/2005/10/pandemic_influenza _awareness_w_2.pp. Accessed 02 November 2007.

24. Lehigh University. 2007. Influenza epidemiology and evolution. Available at: http://www.lehigh.edu/ jas0/V10.html. Accessed 06 November 2007.

25. Ghendon Y. 1994. Introduction to pandemic influenza through history. Eur J Epidemiol. 10: 451-453.

26. Cunha BA. 2004. Influenza: Historical aspects of epidemics and pandemics. Infect Dis Clin North Am. 18: 141-155.

27. Taisuke H \& Kawaoka Y. 2001. Pandemic threat posed by avian influenza A viruses. Clin Microbiol Rev. 14(1): 129-149.

28. Infectious Diseases Society of America (IDSA). 2007. Pandemic influenza. Available at: http://www.cidrap.umn.edu/idsa/influenza/ panflu/biofacts/panflu.html. Accessed 06 November 2007.

29. Weber S, Harder T, Starick E, Beer M, Werner O, Hoffmann B, Mettenleiter TC \& Mundt E. 2007. Molecular analysis of highly pathogenic avian influenza virus of subtype H5N1 isolated from wild birds and mammals in northern Germany. J Gen Virol. 88: 554-558.

30. Bashiruddin JB, Gould AR \& Westbury HA. 1992. Molecular pathotyping of two avian influenza viruses isolated during the Victoria 1976 outbreak. Aust Vet J. 69: 140-142.

31. Cross GM. 1987. The status of avian influenza in poultry in Australia. Avian Dis. 47: 96-103.

32. Nestorowicz A, Kawaoka Y, Bean WJ \& Webster RG. 1987. Molecular analysis of the hemagglutinin genes of Australian H7N7 influenza viruses: Role of passerine birds in maintenance or transmission? Virology. 160: 411-418.

33. Perdue ML, García M, Senne D \& Fraire M. 1997. Virulence-associated sequence duplication at the hemagglutinin cleavage site of avian influenza viruses. Virus Res. 49: 173-186.

34. Wood GW, McCauley JW, Bashiruddin JB \& Alexander DJ. 1993. Deduced amino acid sequences at the haemagglutinin cleavage site of avian influenza A viruses of $\mathrm{H} 5$ and $\mathrm{H} 7$ subtypes. Arch Virol. 130: 209-217.

35. Alexander DJ, Lister SA, Johnson MJ, Randall CJ \& Thomas PJ. 1993. An outbreak of highly pathogenic avian influenza in turkeys in Great Britain in 1991. Vet Rec. 132: 535-536.

36. Eckroade RJ, Silverman LA \& Acland HM. 1998. Avian influenza in Pennsylvania. Avian Dis. 42: 791-795.
37. Kawaoka Y, Nestorowicz A, Alexander DJ \& Webster RG. 1987. Molecular analyses of the hemagglutinin genes of $\mathrm{H} 5$ influenza viruses: Origin of a virulent turkey strain. Virology. 158: 218-227.

38. Röhm C, Süss J, Pohle V \& Webster RG. 1996. Different hemagglutinin cleavage site variants of H7N7 in an influenza outbreak in chickens in Leipzig, Germany. Virology. 218: 253-257.

39. Garcia M, Crawford JM, Latimer JW, Rivera-Cruz E \& Perdue ML. 1996. Heterogeneity in the haemagglutinin gene and emergence of the highly pathogenic phenotype among recent H5N2 avian influenza viruses from Mexico. J Gen Virol. 77: 1493-1504.

40. Horimoto T, Rivera E, Pearson J, Senne D, Krauss S, Kawaoka Y \& Webster RG. 1995. Origin and molecular changes associated with emergence of a highly pathogenic H5N2 influenza virus in Mexico. Virology. 213: 223-230.

41. Naeem K \& Hussain M. 1995 .An outbreak of avian influenza in poultry in Pakistan. Vet Rec. 137(17): 439.

42. Claas EC, Osterhaus AD, van Beek R, De Jong JC, Rimmelzwaan GF, Senne DA, Krauss S, Shortridge KF \& Webster RG. 1998. Human influenza A H5N1 virus related to a highly pathogenic avian influenza virus. Lancet. 351(9101): 472-477.

43. United States Department of Health and Human Services. 2007. The next flu pandemic: Evaluating US preparedness. Available at: http:// www.hhs.gov/asl/testify/t050630d.html. Accessed 06 November 2007.

44. Wagner R, Matrosovich M \& Klenk HD. 2002. Functional balance between haemagglutinin and neuraminidase in influenza virus infections. Rev Med Virol. 12(3): 159-166.

45. Suzuki Y, Ito T, Suzuki T, Holland RE , Chambers TM, Kiso M, Ishida H \& Kawaoka Y. 2000. Sialic acid species as a determinant of the host range of influenza A viruses. J Virol. 74: 11825-11831.

46. Suzuki Y. 2005. Sialobiology of influenza: Molecular mechanism of host range variation of influenza viruses. Biol Pharm Bull. 28: 399408.

47. Gambaryan AS, Tuzikov AB, Pazynina GV, Webster RG, Matrosovich MN \& Bovin NV. 2004. H5N1 chicken influenza viruses display a high binding affinity for Neu5Acalpha2-3Galbeta1-4(6-HSO3) GlcNAc-containing receptors. Virology. 326: 310-316.

48. Gambaryan A, Yamnikova S, Lvov D, Tuzikov A, Chinarev A, Pazynina G, Webster R, Matrosovich M \& Bovin N. 2005. Receptor specificity of influenza viruses from birds and mammals: new data on involvement of the inner fragments of the carbohydrate chain. Virology. 334(2): 276-283.

49. Gambaryan A, Tuzikov A, Pazynina G, Bovin N, Balish A \& Klimov A. 2006. Evolution of the receptor binding phenotype of influenza A (H5) viruses. Virology. 344: 432-438.

50. Couceiro JN, Paulson JC \& Baum, LG. 1993. Influenza virus strains selectively recognize sialyloligosaccharides on human respiratory epithelium; the role of the host cell in selection of hemagglutinin receptor specificity. Virus Res. 29: 155-165.

51. Matrosovich MN, Matrosovich, TY, Gray T, Roberts NA \& Klenk HD. 2004. Human and avian influenza viruses target different cell types in cultures of human airway epithelium. Proc Natl Acad Sci. 101: 4620-4624.

52. Both GW, Sleigh MJ, Cox NJ \& Kendal AP. 1983. Antigenic drift in influenza virus H3 hemagglutinin from 1968 to 1980: Multiple evolutionary pathways and sequential amino acid changes at key antigenic sites. J Virol. 48(1): 52-60.

53. Bonhoeffer S \& Sniegowski P. 2000. In RNA viruses, roughly one nucleotide per genome is incorrectly reproduced in each replication. Nature. 420: 367-369.

54. Steinhauer DA, Torre JC \& Holland JJ. 1989. High nucleotide substitution error frequencies in clonal pools of vesicular stomatitis virus. J Virol. 63: 2072-2080. 
55. Santiago FE \& Rafael S. 2005. Adaptive value of high mutation rates of RNA viruses: Separating causes from consequences. J Virol. 79(18): 11555-11558.

56. Webster RG, Laver WG, Air GM \& Schild GC.1982. Molecular mechanisms of variation in influenza viruses. Nature. 296: 115-121.

57. Bean WJ, Cox NJ \& Kendal AP. 1980. Recombination of human influenza A viruses in nature. Nature. 284: 638-640.

58. Hinshaw VS, Bean WJ, Webster RG \& Sriram G. 1980. Genetic reassortment of influenza A viruses in the intestinal tract of ducks. Virology. 102(2): 412-419.

59. Wilson IA, Skehel JJ \& Wiley DC. 1981. Structure of the haemagglutinin membrane glycoprotein of influenza virus at $3 \AA$ resolution. Nature. 289: 366-373.

60. Robert AL \&Robert MK.1996. Field's Virology, $3^{\text {rd }}$ edn, p 1355. Lippincott-Raven Publication, Philadelphia.

61. Ilyushina NA, Rudneva IA, Shilov AA, Klenk HD \& Kaverin NV. 2005. Postreassortment changes in a model system: HA-NA adjustment in an H3N2 avian-human reassortant influenza virus. Arch Virol. 150(7): 1327-1338.

62. WHO. 2005. Global influenza preparedness plans, the role of WHO and recommendations for national measures before and during pandemics. Available at: http://www.who.int/csr/resources/publications/ influenza/WHO_CDS_CSR_GIP_2005_5/en/ Accessed 06 November 2007.

63. Anonymous. 2007. Influenza plan. Government health site, Canada. Available at: http://www.health.gov.sk.ca/mc_dp_sk_public_ pandemic_influenza_plan.pdf. Accessed 07 November 2007.

64. WHO. 2007. Human cases of avian influenza. Available at:http:// www.who.int/csr/disease/avian_influenza/country/cases_table_2007_ 11_05/n/index.html. Accessed 05 November 2007.

65. Horimoto T \& Kawaoka Y. 2001. Pandemic threat posed by avian influenza A viruses. Clin Microbiol Rev. 14(1): 129-149.

66. WHO. 2007. Consultation on priority public health interventions before and during an influenza pandemic. Available at:http:// www.who.int/csr/disease/avian_influenza/consultation/en. Accessed 05 November 2007.

67. WHO. 2007. Global influenza preparedness plan. Available at: www.cdc.gov/EID/content/13/5/700.htm. Accessed 04 November 2007.

68. Ferguson NM, Cummings DA, Fraser C, Cajka JC, Cooley PC \& Burke DS. 2006. Strategies for mitigating influenza pandemic. Nature. 442(7101): 448-452.

69. McFee RB, Bush LM \& Boehm KM. Avian Influenza: Critical Considerations for the Primary Care Physician. Adv Stud Med. 6(10): 431-440.

70. CDC. 2007. High levels of adamantane resistance among influenza A (H3N2) viruses and interim guidelines for use of antiviral agents. Available at: http://www.cdc.gov/MMWR/preview/mmwrhtml/ mm5502a7.html. Accessed 04 November 2007.

71. WHO. 2007. Avian influenza frequently asked questions. Available at: http://www.who.int/csr/disease/avian_influenza/avian_faqs/en/. Accessed 03 November 2007.

72. Arabi G, Charles D, Ahmed F, Qanta A, Boynton BR \& Memish ZA. 2007. Review: The critically ill avian influenza A (H5N1) patient. Critic Care Med. 35(5): 1397-1403.

73. Crusat M \& Jong MD. 2007. Neuraminidase inhibitors and their role in avian and pandemic influenza. Antivir Ther. 12(4): 593-602.

74. Adelle T. 2006. New antiviral drug shows hope for avian flu treatment. Available at: http://www.flupatrol.com/2006/01/23/antiviralspandemicflu-influenza-avianflu/ Accessed 03 November 2007.
75. Lee CW \& Suarez DL. 2005. Avian influenza virus: Prospects for prevention and control by vaccination. Anim Health Res Rev. 6: $1-15$.

76. IFPMA. 2006. Pandemic influenza vaccines. International Federation of Pharmaceutical Manufacturers and Associations (IFPMA). Available at: http://www.ifpma.org/Influenza/content/pdfs/Table_Avian_ Pandemic_Influenza_RnD_17Oct06.pdf. Accessed 02 November 2007.

77. Treanor JJ, Campbell JD, Zangwill KM, Rowe T \& Wolff M. 2006. Safety and immunogenicity of inactivated subvirion influenza A (H5N1) vaccine. N Engl J Med. 354(13): 1343-1351.

78. Bresson JL, Perronne C, Launay O, Gerdil C, Saville M, Wood J, Hoschler K \& Zambon MC. 2006. Safety and immunogenicity of inactivated split-virion influenza A/Vietnam/1194/2004 (H5N1) vaccine: Phase I randomized trial. Lancet. 367: 1657-1664.

79. Hehme N, Engelmann H, Kuenzel W, Neumeier E \& Saenger R. 2004. Immunogenicity of a monovalent, aluminum-adjuvanted influenza whole virus vaccine for pandemic use. Virus Res. 103: 163-171.

80. Lin J, Zhang J, Dong X, Fang H, Chen J, Su N, Gao Q, Zhang Z, Liu Y, Wang Z, Yang M, Sun R, Li C, Lin S, Ji M, Liu Y, Wang X, Wood J, Feng Z, Wang Y \&Yin W. 2006. Safety and immunogenicity of an inactivated adjuvanted whole-virion influenza A (H5N1) vaccine: A phase I randomised controlled trial. Lancet. 368(9540): 991-997.

81. Vajo Z, Kosa L, Visontay I, Jankovics M \& Jankovics I. 2007. Inactivated whole virus influenza A (H5N1) vaccine. Available at: http:// www.cdc.gov/EID/content/13/5/807.htm. Accessed 03 November 2007.

82. Nicholson KG, Colegate AE, Podda A, Stephenson I, Wood J, Ypma E \& Zambon MC. 2001. Safety and antigenicity of non-adjuvanted and MF59-adjuvanted influenza A/duck/Singapore/97 (H5N3) vaccine: A randomised trial of two potential vaccines against H5N1 influenza. Lancet. 357(9272): 1937-1943.

83. Joan P, Javier D, Ángel BV, Germán SC, José AL, Santiago PH \& David GV. 2007. Effectiveness of MF59 ${ }^{\mathrm{TM}}$-adjuvanted subunit influenza vaccine in preventing hospitalisations for cardiovascular disease, cerebrovascular disease and pneumonia in the elderly. Vaccine. 25(42): 7313-7321.

84. Otfried K, Keith H, Martin S, Walter W, Peter B, Marijan G, Brian AC, Helga S, Ian L, Manfred R, Ines M, Christa T, Leopold GR, Wolfgang M, Falko GF \& Barrett PN. 2007. Cell culture (Vero) derived whole virus (H5N1) vaccine based on wild-type virus strain induces cross-protective immune responses. Vaccine. 25(32): 6028-6036.

85. IFPMA. 2006. R\&D for Avian/pandemic influenza vaccines. International Federation of Pharmaceutical Manufacturers and Associations (IFPMA). Available at: http://www.ifpma.org/Influenza/ content/pdfs/Table_Avian_Pandemic_Influenza_RnD_17Oct06.pdf. Accessed 03 November 2007.

86. Sabine N, Tom D, Xavier S, Peter V, Willy MJ \& Walter F. 1999. A universal influenza A vaccine based on the extracellular domain of the M2 protein. Nat Med. 5: 1157-1163.

87. Demetrius M, Albert C, Jose M.\& Galarza JM. 2007. A novel intranasal virus-like particle (VLP) vaccine designed to protect against the pandemic 1918 influenza A virus (H1N1). Virol Immunol. 20(3): 441-452.

88. Webster RG \& Laver WG. 1980. Determination of the number of nonoverlapping antigenic areas on Hong Kong (H3N2) influenza virus hemagglutinin with monoclonal antibodies and the selection of variants with potential epidemiological significance. Virology. 104: 139-148.

89. Murphy B \& Webster R. 1996. Field's Virology, $3^{\text {rd }}$ edn, pp 13971445. Lippincott, Philadelphia. 
90. Marangon S \& Busani L. 2007. The use of vaccination in poultry production. Rev Sci Tech. 26(1): 265-274.

91. Anonymous. 2007. Agriculture, Pêcheries et Alimentation Quebec. Canadian government site. Available at: http://www.mapaq.gouv.qc.ca/ NR/rdonlyres/79EB5A72-464A-48B5-B7A3481803ED4D75/0/ TCN10nov05.pdf. Accessed 04 November 2007.

92. Bennun L. 2007. Reality takes wing over bird flu. Available at: http:// news.bbc.co.uk/1/hi/sci/tech/4721598.stm. Accessed 02 November 2007.

93. Paul E. 2006. Infectious disease and the evolution of virulence. Available at: http://www.pbs.org/wgbh/evolution/library/01/6/l_016_06.html. Accessed 05 November 2007.

94. Boatwright S \& McKissick J. 2004. Georgia farm gate value report. University of Georgia. Available at: http://www.caed.uga.edu/ staffreports_files/2004\%20Farm\%20Gate\%20Value\%20Report.pdf. Accessed 23 October 2007.

95. Capua I \& Alexander DJ. 2004. Avian influenza recent developments. Avian Pathol. 33: 393-404.
96. Michael G. 2006. Bird flu: A Virus of Our Own Hatching, p 465. Lantern Books, New York.

97. Ewald CH \& Havenith U. 1994. Factors associated with the occurrence of influenza A virus infections in fattening swine. Berl Münch Tierärztl Wschr. 107: 256-262.

98. FAO. 2007. Combination of fish-chicken and fish-chicken-duck systems did not show notable differences in terms of fish production, profitability, etc. Available at: http://www.fao.org/docrep/field/009/ ag187e/AG187E01.htm. Accessed 03 November 2007.

99. Michael M. 2005. Bird flu could be linked to fish farming. New Zealand Herald, December 28. Available at: http://www.nzherald.co.nz/section/ story.cfm?c_id=2\&ObjectID=10361729. Accessed 03 November 2007.

100. Anonymous. 2007. The welfare of chickens kept for meat production (Broilers). European Commission Scientific Committee on Animal Health and Animal Welfare. Available at: http://europa.eu.int/comm/ food/fs/sc/scah/out39_en.pdf. Accessed 01 November 2007.

101. Frederick MA. 1999. The threat posed by the global emergence of livestock, food-borne, and zoonotic pathogens. Ann NY Acad Sci. 894: $20-27$. 